\title{
Peculiarities of Airway Inflammation and Lipid Peroxidation in the Development of Hyperosmotic Airway Hyperresponsiveness in Patients with Asthma
}

\author{
Alexey B. Pirogov, $\mathrm{PhD}^{1}$; Anna G. Prikhodko, $\mathrm{PhD}, \mathrm{ScD}^{1}$; Juliy M. Perelman, $\mathrm{PhD}, \mathrm{ScD}^{1}$; \\ Eugene A. Borodin, $\mathrm{PhD}, \mathrm{ScD}^{2}$; Denis E. Naumov, $\mathrm{PhD}^{1 *}$; Sergey V. Zinovyev, $\mathrm{PhD}^{2}$; \\ Mikhail A. Shtarberg, $\mathrm{PhD}^{2}$ \\ ${ }^{1}$ Far Eastern Scientific Center of Physiology and Pathology of Respiration, Blagoveshchensk, Russia \\ ${ }^{2}$ Amur State Medical Academy, Blagoveshchensk, Russia
}

\begin{abstract}
The aim of our study was to evaluate the role of airway cellular inflammation and the lipid peroxidation level in the development of airway hyperresponsiveness (AHR) to inhalation of hypertonic saline (IHS).

Methods and Results: The study included the estimation of inflammatory-cellular composition, intracellular concentration of myeloperoxidase (MPO) in induced sputum (IS), serum levels of lipid hydroperoxides (LHP), ceruloplasmin, and vitamin E in 29 patients with asthma and 12 healthy persons. AHR to IHS was assessed by spirometry after 3-min IHS via ultrasonic nebulizer. Patients with asthma had higher indices of leukocytes destruction and cytolysis intensity with the increased leukocyte count in IS. Maximum values of neutrophils cytolysis intensity and leukocytic MPO were found in IS of the patients with AHR to IHS. After the bronchial provocation, serum concentration of LHP was higher in these patients in comparison with the patients without the AHR and control groups. In addition, patients with asthma had lower level of antioxidants than healthy subjects.

Conclusion: Marked inflammation involving MPO-activated leukocytes and intensive lipid peroxidation underlie the excessive airway response to IHS. (Int J Biomed. 2016; 6(4):259-264.)
\end{abstract}

Keywords: bronchial provocation $\bullet$ bronchoconstriction $\bullet$ hypertonic saline $\bullet$ myeloperoxidase $\bullet$ oxidative stress

\section{Abbreviations}

AHR, airway hyperresponsiveness; CP, ceruloplasmin; IHS, inhalation of hypertonic saline; HOCI, hypochlorous acid; ICD, index of cells destruction; IC, index of cytolysis; IS, induced sputum; LHP, lipid hydroperoxides; LP, lipid peroxidation; MPO, myeloperoxidase; ROS, reactive oxygen species; RHS, reactive halogen species; VitE, vitamin E.

\section{Introduction}

A high lability of the airways and bronchoconstriction caused by exogenous stimuli in patients with asthma are fully revealed under the inhalation of hyperosmotic solutions, ${ }^{[1,2]}$

*Corresponding author: Denis E. Naumov. PhD. Laboratory of Prophylaxis of Nonspecific Lung Diseases, Far Eastern Scientific Center of Physiology and Pathology of Respiration; Blagoveshchensk, Russia.E-mail: denn1985@bk.ru but in spite of the prevalence of hyperosmotic airway reaction, its mechanisms remain largely unexplored.

According to the view that oxidative stress plays a leading role in the pathogenesis of chronic obstructive pulmonary disease and asthma, ${ }^{[3,4]}$ ROS, peroxynitrite and hypochlorite may serve as the inducers of bronchoconstriction. ${ }^{[3,5,6]}$ Irreversible oxidative changes in proteins, lipids, and nucleic acids, as well as the damage to biomembranes by free-radical oxidation, are usually associated with the increased consumption and exhaustion of antioxidant protection..$^{[7,8]}$ 
If the genesis of AHR in asthma patients is associated with the stress damage to proteins and glycoproteins and to the inactivation of tissue receptors, the development of exudation and further stages of bronchial inflammation is caused by LP. ${ }^{[3]}$ LP metabolites play an important role in enhancing airway response to osmotic stimuli and provoke the loss of asthma control. ${ }^{[9]}$ It is established that LP processes are initiated not only by ROS, but also by halogen-containing reagents - the products of halogenides oxidation, which are catalyzed by MPO in the presence of $\mathrm{H}_{2} \mathrm{O}_{2} \cdot{ }^{[10,11]}$ Highly reactive hypohalous acids formed in the system of $\mathrm{H}_{2} \mathrm{O}_{2}$-MPO and their derivatives - secondary RHS along with ROS and reactive nitrogen species -determine the efficacy of the cellular response under induction and maintenance of inflammation, ${ }^{[10]}$ thus providing the interrelation between oxidative and halogenating stress. ${ }^{[11]}$

The main source of ROS and RHS is primed neutrophilic leukocytes ${ }^{[12]}$ depositing MPO in azurophilic granules and secreting the enzyme into extracellular media through degranulation. ${ }^{[10]}$ In our previous studies we found the elevated level of MPO activity is associated with high intensiveness of degranulation and destruction of leukocytes in IS of asthma patients with AHR to hypoosmotic and cold triggers. ${ }^{[13,14]}$

In light of a well-established connection between oxidative stress and inflammation in asthma, the relationship between airway inflammation and LP in the formation of excessive airway response to osmotic stimulus deserves special attention. The aim of our study was to evaluate the role of airway cellular inflammation and the LP level in the development of AHR to IHS.

\section{Materials and Methods}

The study enrolled 27 patients aged from 31 to 55 years (mean age $41.0 \pm 1.8$ years) of both sexes (17 females and 10 males) with mild, persistent, partly controlled and uncontrolled, physician-diagnosed asthma according to GINA criteria. ${ }^{[15]}$ The control group included 12 healthy subjects without a history of smoking, upper airway pathology, allergic diseases, or acute respiratory infections during the previous 3 months, matched by age and gender with the asthma patient group. This study was performed in accordance with the Declaration of Helsinki and was approved by Local Committee of Biomedical Ethics of the Far Eastern Scientific Center of Physiology and Pathology of Respiration. Written informed consent was obtained from all participants. Preliminary examination included the analysis of clinical symptoms, the estimation of asthma control by an Asthma Control Test questionnaire (Quality Metric Inc., 2002), the assessment of lung function by standard spirometry (Easy on-PC, nddMedizintechnik AG, Switzerland) with further testing for reversibility of airway obstruction 15 minutes after inhalation of $200 \mathrm{mcg}$ of salbutamol.

We conducted the bronchial challenge test with 3-minute IHS $\left(4.5 \% \mathrm{NaCl}\right.$ at $\left.37^{\circ} \mathrm{C}\right)$ via ultrasonic nebulizer to define the airway response to hyperosmotic stimuli. Inhaled corticosteroids and bronchodilators were withdrawn at least 12 hours before the challenge. Spirometry and blood sampling for biochemical study were done before and after the test.
Osmotic AHR to IHS was diagnosed at the fall of $\mathrm{FEV}_{1}$ by $10 \%$ or more from the initial value.

The collection of IS was performed using the standard methodology the day after the challenge test with IHS to improve the tolerance of the procedure. IS was collected after the estimation of lung function parameters and inhalation of salbutamol in the dose of $200 \mathrm{mcg}$. Sputum induction was done by successive 7 -min inhalations of $3 \%, 4 \%$ and $5 \%$ solutions of $\mathrm{NaCl}$ via ultrasonic nebulizer (OMRON NE-U-17, Japan) at a constant flow of $3 \mathrm{ml} / \mathrm{min}$. The inhalation was stopped when a satisfactory sputum sample was obtained or the $\mathrm{FEV}_{1}$ value fell by more than $10 \%$ from the baseline.

The study of IS samples was done within 2 hours after collection. IS cell count was calculated with a haemocytometer. The smears were stained in a $4 \%-5 \%$ water solution of Romanowsky-Giemsa dye at $\mathrm{pH}$ 6.8. Only samples with the minimal level of squamous epithelium contamination (less than $20 \%$ ) were included in the analysis. ${ }^{[16]}$ The calculated number of neutrophilic and eosinophilic leukocytes, macrophages, lymphocytes and bronchial epithelium cells were expressed as a percent of total cell count.

MPO activity in leukocytes was evaluated by GrahamKnoll cytochemical method ${ }^{[17]}$ in cytological smears of IS with additional Azure-2 staining. Images of microslides were captured by DCM 510 digital camera (Hangzhou Scopetek Opto-Electric Co.,Ltd.) and processed in ImageTool, Optika Vision Pro and MBF ImageJ software. Mean cytochemical coefficient (MCC) of MPO (in pixels) was calculated based on the optical density of the cells obtained by microdensitometry.

The degree and intensity of the destruction in neutrophilic and eosinophilic leukocytes were defined as one of 5 classes depending on the changes in structural integrity of cell elements. The degree of cell destruction was expressed as total ICD. In addition, IC was calculated as the ratio of the number of destroyed cells to the total cell count:

$$
\begin{aligned}
& \mathrm{ICD}=\left(\mathrm{n}_{1}+\mathrm{n}_{2}+\mathrm{n}_{3}+\mathrm{n}_{4}\right): 100 \\
& \mathrm{IC}=\mathrm{n}_{4}:\left(\mathrm{n}_{0}+\mathrm{n}_{2}+\mathrm{n}_{3}+\mathrm{n}_{4}\right),
\end{aligned}
$$

where $0,1,2,3$, and 4 - the class of destruction; $n_{0}, n_{1,} n_{2}, n_{3}$ and $\mathrm{n}_{4}$ - the number of cells of the corresponding destruction class.

The cytolysis intensity was evaluated as the ratio of $\mathrm{ICD} / \mathrm{IC}$.

The levels of oxidative stress and antioxidant protection were studied in the blood serum. To estimate the concentration of LP products (LHP), we used a method based on the capability of LHP to oxidize $\mathrm{Fe}^{2+}$ into $\mathrm{Fe}^{3+}$ with further reaction of $\mathrm{Fe}^{3+}$ with ammonium thiocyanate.

The content of VitE was assayed in blood lipid extracts by the color reaction with dipyridyl and $\mathrm{FeCl}_{3}$. The content of $\mathrm{CP}$ in the blood serum was measured by simple calorimetric method developed by Ravin and based on the oxydation of p-phenylenediamine in the presence of ceruloplasmin.

Statistical analysis was performed using Statistica 8 software package (StatSoft Inc., Tulsa, OK, USA, 2008). All values are presented as mean \pm standard error of the mean or as number (percentage). Student's paired t-tests was used to compare two groups for data with normal distribution. Multiple comparisons were performed with one-way ANOVA 
and Tukey's HSD test. Pearson's correlation coefficient (r) was used to determine the strength of the relationship between the two continuous variables. A probability value of $P<0.05$ was considered statistically significant.

\section{Results}

According to the results of bronchoprovocation, patients were divided into 2 groups: Group $1(\mathrm{n}=10)$ with AHR to IHS and Group $2(\mathrm{n}=19)$ without the response to IHS. Patients with positive response to osmotic stimulus had the lowest values of $\mathrm{FEF}_{25-75}$, what suggested a decreased conductance of distal bronchi (Table 1).

Table 1.

Comparative characteristic of the studied groups

\begin{tabular}{|c|c|c|c|c|}
\hline Parameter & $\begin{array}{l}\text { Group } 1 \\
\text { (1) }\end{array}$ & $\begin{array}{c}\text { Group } 2 \\
(2)\end{array}$ & $\begin{array}{l}\text { Control } \\
\text { group } \\
(3)\end{array}$ & Statistics \\
\hline Age, y & $43.0 \pm 2.9$ & $39.8 \pm 1.8$ & $37.1 \pm 3.0$ & $\begin{array}{l}\text { ANOVA P }=0.3178 \\
\text { Tukey's HSD } \\
\mathrm{P}_{1-2}=0.6350 ; \mathrm{P}_{1-3}=0.2852 ; \\
\mathrm{P}_{2-3}=0.6950\end{array}$ \\
\hline Height, cm & $167.6 \pm 1.3$ & $172.6 \pm 2.7$ & $171.2 \pm 3.7$ & $\begin{array}{l}\text { ANOVA } \mathrm{P}=0.5012 \\
\text { Tukey's HSD } \\
\mathrm{P}_{1-2}=0.4704 ; \mathrm{P}_{1-3}=0.7192 ; \\
\mathrm{P}_{2-3}=0.9345\end{array}$ \\
\hline Weight, kg & $83.8 \pm 6.5$ & $84.6 \pm 2.9$ & $79.9 \pm 3.6$ & $\begin{array}{l}\text { ANOVA } \mathrm{P}=0.7550 \\
\text { Tukey's HSD } \\
\mathrm{P}_{1-2}=0.9923 ; \mathrm{P}_{1-3}=0.8595 ; \\
\mathrm{P}_{2-3}=0.7444\end{array}$ \\
\hline $\begin{array}{l}\text { Gender, } \mathrm{n} / \% \\
\text { male } \\
\text { female }\end{array}$ & $\begin{array}{l}5 / 50 \\
5 / 50\end{array}$ & $\begin{array}{c}8 / 42.1 \\
11 / 57.9\end{array}$ & $\begin{array}{l}6 / 50 \\
6 / 50\end{array}$ & $\begin{array}{l}\mathrm{X}^{2}=0.256 \\
\mathrm{P}=0.8798\end{array}$ \\
\hline $\begin{array}{l}\text { Asthma } \\
\text { history, y }\end{array}$ & $2.4 \pm 0.63$ & $4.7 \pm 1.0$ & - & $P_{1-2}=0.1271$ \\
\hline ACT score & $18.0 \pm 1.7$ & $18.6 \pm 1.3$ & - & $P_{1-2}=0.7849$ \\
\hline $\mathrm{FEV}_{1}, \%$ & $89.8 \pm 4.9$ & $95.8 \pm 5.7$ & $103.6 \pm 1.6$ & $\begin{array}{l}\text { ANOVA P }=0.2397 \\
\text { Tukey's HSD } \\
\mathrm{P}_{1-2}=0.6983 ; \mathrm{P}_{1-3}=0.2172 ; \\
\mathrm{P}_{2-3}=0.5092\end{array}$ \\
\hline $\mathrm{FEV}_{1} / \mathrm{FVC}$ & $0.70 \pm 0.02$ & $0.74 \pm 0.02$ & $0.84 \pm 0.01$ & $\begin{array}{l}\text { ANOVA P }=0.0001 \\
\text { Tukey's HSD } \\
\mathrm{P}_{1-2}=0.3196 ; \mathrm{P}_{1-3}=0.0001 ; \\
\mathrm{P}_{2-3}=0.0012\end{array}$ \\
\hline $\mathrm{FEF}_{25-75}, \%$ & $53.0 \pm 2.0$ & $70.9 \pm 5.1$ & $98.8 \pm 3.77$ & $\begin{array}{l}\text { ANOVA P }=0.0000 \\
\text { Tukey's HSD } \\
\mathrm{P}_{1-2}=0.0287 ; \mathrm{P}_{1-3}=0.0000 ; \\
\mathrm{P}_{2-3}=0.0002\end{array}$ \\
\hline $\begin{array}{l}\Delta \mathrm{FEV}_{\text {lfenoterol }} \\
\%\end{array}$ & $16.7 \pm 6.5$ & $11.1 \pm 3.9$ & - & $P_{1-2}=0.4393$ \\
\hline $\begin{array}{l}\Delta \mathrm{FEV}_{1 \mathrm{IHS}}, \\
{ }_{0}\end{array}$ & $-15.8 \pm 2.1$ & $-0.6 \pm 1.5$ & $-0.98 \pm 1.1$ & $\begin{array}{l}\text { ANOVA P }=0.0000 \\
\text { Tukey's HSD } \\
\mathrm{P}_{1-2}=0.0000 ; \mathrm{P}_{1-3}=0.0000 ; \\
\mathrm{P}_{2-3}=0.9834\end{array}$ \\
\hline $\begin{array}{l}\text { Amount of } \\
\text { delivered } \\
\text { aerosol du- } \\
\text { ring HIS, g }\end{array}$ & $3.5 \pm 0.22$ & $3.2 \pm 0.19$ & $5.1 \pm 0.33$ & $\begin{array}{l}\text { ANOVA } \mathrm{P}=0.0000 \\
\text { Tukey's HSD } \\
\mathrm{P}_{1-2}=0.6752 ; \mathrm{P}_{1-3}=0.0005 ; \\
\mathrm{P}_{2-3}=0.0000\end{array}$ \\
\hline
\end{tabular}

In the inflammatory pattern of asthma patients there was a prevalence of eosinophils and neutrophils count against the background of an elevated number of lymphocytes and double reduction of macrophages in comparison with the control group (Table 2). The neutrophilic granulocytes tended to dominate in IS of patients of Group 1 than in those of Group 2 and the control group, and were accompanied by a lower macrophage count and an enhanced desquamation of bronchial epithelium.

Table 2.

\section{Cellular composition of induced sputum}

\begin{tabular}{|c|c|c|c|c|}
\hline Parameter & $\begin{array}{c}\text { Group } 1 \\
(1)\end{array}$ & $\mid \begin{array}{c}\text { Group } 2 \\
(2)\end{array}$ & $\begin{array}{l}\text { Control } \\
\text { group } \\
\text { (3) }\end{array}$ & Statistics \\
\hline $\begin{array}{l}\text { Neutrophils, } \\
\%\end{array}$ & $38.9 \pm 5.0$ & $25.5 \pm 4.8$ & $11.6 \pm 0.7$ & $\begin{array}{l}\text { ANOVA P }=0.0017 \\
\text { Tukey's HSD } \\
\mathrm{P}_{1-2}=0.1045 ; \mathrm{P}_{1-3}=0.0011 ; \\
\mathrm{P}_{2-3}=0.0677\end{array}$ \\
\hline $\begin{array}{l}\text { Eosinophils, } \\
\%\end{array}$ & $24.5 \pm 5.7$ & $19.2 \pm 3.3$ & $0.1 \pm 0.08$ & $\begin{array}{l}\text { ANOVA P }=0.0002 \\
\text { Tukey's HSD } \\
\mathrm{P}_{1-2}=0.5656 ; \mathrm{P}_{1-3}=0.0003 ; \\
\mathrm{P}_{2-3}=0.0010\end{array}$ \\
\hline $\begin{array}{l}\text { Macrophages, } \\
\%\end{array}$ & $30.2 \pm 8.2$ & $49.3 \pm 5.3$ & $84.8 \pm 0.9$ & $\begin{array}{l}\text { ANOVA P }=0.0000 \\
\text { Tukey's HSD } \\
\mathrm{P}_{1-2}=0.0545 ; \mathrm{P}_{1-3}=0.0000 ; \\
\mathrm{P}_{2-3}=0.0001\end{array}$ \\
\hline $\begin{array}{l}\text { Lymphocytes, } \\
\%\end{array}$ & $3.6 \pm 0.97$ & $4.2 \pm 0.89$ & $2.4 \pm 0.3$ & $\begin{array}{l}\text { ANOVA P }=0.3020 \\
\text { Tukey's HSD } \\
\mathrm{P}_{1-2}=0.8747 ; \mathrm{P}_{1-3}=0.6428 ; \\
\mathrm{P}_{2-3}=0.2709\end{array}$ \\
\hline $\begin{array}{l}\text { Epithelium, } \\
\%\end{array}$ & $2.1 \pm 0.86$ & $0.5 \pm 0.15$ & $0.9 \pm 0.2$ & $\begin{array}{l}\text { ANOVA P }=0.0254 \\
\text { Tukey's HSD } \\
\mathrm{P}_{1-2}=0.0197 ; \mathrm{P}_{1-3}=0.1422 ; \\
\mathrm{P}_{2-3}=0.7356\end{array}$ \\
\hline
\end{tabular}

Analysis of cytomorphologic parameters of destruction and intensiveness of cytolysis in asthma patients showed an activation of these processes in comparison with the control group (Table 3). In Group 2, the ICD degree was increased and the destructive changes of eosinophils and neutrophils prevailed over their cytolysis. At the same time, in patients with a positive response to IHS, we observed a high degree of cytolic activity of neutrophils with high values of neutrophilic ICD/IC.

Table 3.

Cytomorphologic parameters of eosinophilic and neutrophilic destruction and intensiveness of cytolysis in induced sputum

\begin{tabular}{|l|c|c|c|c|}
\hline \multirow{2}{*}{ Group } & \multicolumn{2}{|c|}{ Eosinophils } & \multicolumn{2}{c|}{ Neutrophils } \\
\cline { 2 - 5 } & ICD & ICD/IC & ICD & ICD/IC \\
\hline $\begin{array}{l}\text { Group 1 } \\
\text { (1) }\end{array}$ & $0.40 \pm 0.03$ & $0.29 \pm 0.04$ & $0.38 \pm 0.02$ & $0.44 \pm 0.02$ \\
\hline $\begin{array}{l}\text { Group 2 } \\
\text { (2) }\end{array}$ & $0.47 \pm 0.02$ & $0.31 \pm 0.02$ & $0.51 \pm 0.02$ & $0.28 \pm 0.02$ \\
\hline $\begin{array}{l}\text { Control } \\
\text { group } \\
\text { (3) }\end{array}$ & $0.22 \pm 0.06$ & $0.08 \pm 0.006$ & $0.19 \pm 0.09$ & $0.11 \pm 0.007$ \\
\hline $\begin{array}{l}\text { ANOVA } \\
\text { statistics }\end{array}$ & $\begin{array}{l}\mathrm{P}=0.0001 \\
\text { Tukey's HSD } \\
\mathrm{P}_{1-2}=0.3894 \\
\mathrm{P}_{1-3}=0.0096 \\
\mathrm{P}_{2-3}=0.0000\end{array}$ & $\begin{array}{l}\mathrm{P}=0.0000 \\
\text { Tukey's HSD } \\
\mathrm{P}_{1-2}=0.8260 \\
\mathrm{P}_{1-3}=0.0000 \\
\mathrm{P}_{2-3}=0.0000\end{array}$ & $\begin{array}{l}\mathrm{P}=0.0001 \\
\text { Tukey's HSD } \\
\mathrm{P}_{1-2}=0.1703 \\
\mathrm{P}_{1-3}=0.0483\end{array}$ & $\begin{array}{l}\mathrm{P}=0.0000 \\
\mathrm{P}_{2-3}=0.0001\end{array}$ \\
$\begin{array}{l}\mathrm{P}_{1-2}=0.00000 \\
\mathrm{P}_{1-3}=0.0000 \\
\mathrm{P}_{2-3}=0.0000\end{array}$ \\
\hline
\end{tabular}


MPO MCC in IS of Group 1 patients $(142.5 \pm 10.98$ px) was significantly higher than in Group 2 patients $(97.89 \pm 11.43 \mathrm{px} ; P=0.01)$ and exceeded the value of the control group $(84.8 \pm 4.06 \mathrm{px}, P<0.001)$, which suggested the intensification of intracellular MPO activity.

Evaluation of the basic level of serum LHP in asthma patients with AHR to IHS revealed higher values of this parameter in comparison with the control group (Table 4). After the challenge with IHS, the concentration of LHP increased in both groups but to a greater extent in Group 1. In these patients, enhanced production of LHP after the test was well correlated with high responsiveness of small bronchi $\left(\triangle \mathrm{FEF}_{50}\right)$ to IHS $(\mathrm{r}=-0.75 ; P=0.02)$.

Table 4.

LHP, VitE and CP before and after the challenge with IHS

\begin{tabular}{|c|c|c|c|c|c|}
\hline \multicolumn{2}{|c|}{ Variable } & \multirow{2}{*}{$\begin{array}{c}\text { Group } 1 \\
\text { (1) } \\
16.5 \pm 0.6\end{array}$} & \multirow{2}{*}{$\begin{array}{c}\begin{array}{c}\text { Group } 2 \\
(2)\end{array} \\
14.6 \pm 0.6\end{array}$} & \multirow{2}{*}{\begin{tabular}{|c|}
$\begin{array}{c}\text { Control } \\
\text { group } \\
(3)\end{array}$ \\
$12.4 \pm 1.2$
\end{tabular}} & \multirow{2}{*}{\begin{tabular}{l}
\multicolumn{1}{c}{ Statistics } \\
ANOVA P $=0.0109$ \\
Tukey's HSD \\
$\mathrm{P}_{1-2}=0.2528 ; \mathrm{P}_{1-3}=0.0082 ;$ \\
$\mathrm{P}_{2-3}=0.1314$
\end{tabular}} \\
\hline \multirow{3}{*}{$\begin{array}{l}\text { LHP, } \\
\mathrm{nM} / \mathrm{ml}\end{array}$} & $\begin{array}{l}\text { Before } \\
\text { TwIHS }\end{array}$ & & & & \\
\hline & $\begin{array}{l}\text { After } \\
\text { TwIHS }\end{array}$ & $19.8 \pm 1.0$ & $16.2 \pm 0.8$ & & $P_{1-2}=0.0112$ \\
\hline & $\mathrm{P}$ & 0.08 & 0.17 & & \\
\hline $\begin{array}{l}\Delta \mathrm{LHP} \\
\mathrm{nM} / \mathrm{ml}\end{array}$ & & $3.30 \pm 0.7$ & $1.31 \pm 0.67$ & & $\mathrm{P}_{1-2}=0.0706$ \\
\hline \multirow{3}{*}{$\begin{array}{l}\text { VitE, } \\
\mathrm{mcg} / \mathrm{ml}\end{array}$} & $\begin{array}{l}\text { Before } \\
\text { TwIHS }\end{array}$ & $33.4 \pm 1.6$ & $30.0 \pm 0.8$ & $38.1 \pm 1.5$ & $\begin{array}{l}\text { ANOVA P }=0.0001 \\
\text { Tukey's HSD } \\
\mathrm{P}_{1-2}=0.1351 ; \mathrm{P}_{1-3}=0.0459 \\
\mathrm{P}_{2-3}=0.0000\end{array}$ \\
\hline & $\begin{array}{l}\text { After } \\
\text { TwIHS }\end{array}$ & $34.8 \pm 1.8$ & $29.9 \pm 1.2$ & & $\mathrm{P}_{1-2}=0.0277$ \\
\hline & $\mathrm{P}$ & 0.49 & 0.91 & & \\
\hline $\begin{array}{l}\Delta \mathrm{VitE}, \\
\mathrm{mcg} / \mathrm{ml}\end{array}$ & & $1.4 \pm 1.40$ & $-0.1 \pm 1.08$ & & $\mathrm{P}_{1-2}=0.4128$ \\
\hline \multirow{3}{*}{$\begin{array}{l}\mathrm{CP}, \\
\mathrm{mg} / 100 \mathrm{ml}\end{array}$} & $\begin{array}{l}\text { Before } \\
\text { TwIHS }\end{array}$ & $23.2 \pm 1.0$ & $23.1 \pm 2.3$ & $33.8 \pm 2.9$ & $\begin{array}{l}\text { ANOVA P }=0.0051 \\
\text { Tukey's HSD } \\
\mathrm{P}_{1-2}=1.0180 ; \mathrm{P}_{1-3}=0.0223 \\
\mathrm{P}_{2-3}=0.0065\end{array}$ \\
\hline & $\begin{array}{l}\text { After } \\
\text { TwIHS }\end{array}$ & $23.3 \pm 0.9$ & $21.8 \pm 1.1$ & & $P_{1-2}=0.3738$ \\
\hline & $\mathrm{P}$ & 0.85 & 0.51 & & \\
\hline $\begin{array}{l}\Delta \mathrm{CP} \\
\mathrm{mg} / 100 \mathrm{ml}\end{array}$ & & $0.10 \pm 0.6$ & $-1.30 \pm 1.6$ & & $P_{1-2}=0.5418$ \\
\hline
\end{tabular}

TwIHS - test with IHS

There was initially a lower concentration of CP in both groups of patients in relation to healthy people. The challenge with IHS did not produce any dynamics of CP level in the studied subjects. In addition, a close correlation was found between the initial $\mathrm{CP}$ level and the response of small bronchi $\left(\Delta \mathrm{FEF}_{50}\right)$ to $\mathrm{IHS}(\mathrm{r}=0.73 ; P=0.03)$.
The level of VitE as another antioxidant in asthma patients initially was lower than in healthy subjects. Similarly to $\mathrm{CP}$, there was no significant dynamics of VitE in both groups of patients after the test with IHS, so its level remained relatively constant.

\section{Discussion}

Most of the IS cells in patients with AHR to IHS were neutrophils, though eosinophils were also presented in this group and their inflammatory pattern may be characterized as combined neutrophilic-eosinophilic. The same phenotype has been observed before in asthma patients with the bronchial response triggered by cold. ${ }^{[18,19]}$ However, it differed from the inflammatory pattern found in patients with AHR to hypoosmotic stimulus, in which eosinophilic granulocytes prevailed in IS. ${ }^{[20]}$

According to the literature, cytolysis along with cell degranulation serves as one of the forms of pro-inflammatory enzymes released from leukocytes. ${ }^{[10]}$ Cell destruction of varying degrees does not always lead to cell death and may represent one of the morphological and cytological equivalents of degranulation. Cytolysis, rather than destruction, is associated with the influence of damaging factors that cause the loss of cell membrane integrity and isolation of the cell from its surroundings with further development or progression of inflammation. ${ }^{[4]}$

It is most likely that the increased cytolysis of neutrophils and the necrotic path of leukocyte death in patients with asthma who have AHR to IHS occurs due to a serious inflammatory stimulation of synthesis and secretion of MPO into extracellular space.

LP level is closely associated with the accumulation of MPO in leukocyte granules, which release under cellular destruction, and cytolysis and catalytic production of RHS. LHPs are considered to be traditional indicators of LP in biological systems. As is known, diene conjugates and LHP are formed by the free-radical mechanism of interaction between the primary RHS and unsaturated bonds of phospholipid acyl chains. ${ }^{[2]}$ The role of the initiating link in RHS-induced LP is given to the reaction of $\mathrm{HOCl}$ with the hydroperoxide group, which is always present in the unsaturated lipid as a result of its natural oxygenation. This process is accompanied by the formation of peroxyl radicals with their further transformation into alkoxyl radicals. ${ }^{[11,21]}$ It has been proven that MPO in the presence of its substrates $\left(\mathrm{H}_{2} \mathrm{O}_{2}\right.$ and $\left.\mathrm{Cl}^{-}\right)$breaks down activated hydroperoxide with the formation of O-centered radicals identified as peroxyl and alkoxyl. ${ }^{[1]]}$ It is also supposed that with the hydroperoxides of fatty acids, it is possible that some quantity of singlet oxygen, besides O-centered radicals, could be formed. Inhibitory analysis conducted with $\mathrm{HOCl}$ "traps," interceptors of free radicals and MPO inhibitors, showed that the disruption of the hydroperoxy group in the presence of isolated MPO or activated neutrophils was caused by direct enzyme activity. ${ }^{[11]}$

An initially high content of LHP in the blood serum in patients with asthma, and its further increase after the challenge in Group 1, indicated the mobilization of a free- 
radical oxidation cascade involving different organ systems. The obtained data on cytological and cytochemical analysis of IS corresponded to initially increased LHPs with their further growth after the bronchial challenge test in Group 1. The more intensive were the processes of neutrophils cytolysis and MPO accumulation, the higher were the level of LHPs in the blood. This serves as an evidence of the participation of RHS formed at MPO-dependent catalysis in the generation of LP products.

The scale of halogenating stress is determined not only by the amount and activity of MPO secreted into extracellular space but also by the efficacy of the natural interceptors of RHS. CP is the most effective interceptor of $\mathrm{HOCl}$ along with glutathione, taurine, ascorbate and urate, which also have very high reaction rate constants with HOCI. ${ }^{[22]}$ The increase of neutrophilic and eosinophilic granulocytes in IS with high ICD and ICD/IC and elevated intracellular MPO in asthma patients with AHR to IHS indicates the activation of synthesis and release of MPO in these subjects. The deficit of CP observed in asthma patients most likely was caused by rising inflammation and the shift of redox status to prooxidants. In halogenating or oxidative stress, the low level of $\mathrm{CP}$ is associated with the disturbance of its ability to form complexes with MPO and inhibit both the chlorinating and peroxide activity of the enzyme. ${ }^{[23,24]}$

The low concentration of VitE found in asthma patients has an unfavorable prognostic effect on the treatment of the disease. VitE is able to regulate the biotransformation and pharmacological effect of drugs by changing the activity of xenobiotic-metabolizing enzymes, including the system of cytochrome P450. Cytochrome P450 3A4 is the most functionally important among the cytochrome P450 family as it metabolizes 637 substrates and participates in metabolism of $50 \%$ of currently used medicaments. ROS can interact with cytochrome P450, inducing inactivation of the enzyme. Vitamin C, vitamin A and VitE also influence the catalytic activity of cytochrome P450-3A4. As the reduction of cytochrome $\mathrm{P} 450$ heme is the main stage in catalysis and is accompanied by generation of ROS, VitE influences catalytic functions of this hemoprotein. The influence of ROS "traps," including VitE, on electrocatalysis has been recently discussed in the literature. ${ }^{[25]}$

Enhanced inflammation with high activity of neutrophilic and eosinophilic leukocytes, deposition and exocytosis of MPO at cellular destruction, and cytolysis in combination with escalation of oxidative and halogenating stress are engaged in the development of AHR to IHS in asthma. In these patients, an elevated level of serum LHP is accompanied by incomplete neutralization of LP toxic molecules due to the decreased concentrations of antioxidants. Further study of MPO and LP as markers of osmotic AHR may be useful in connection with asthma therapy to achieve optimal disease control.

\section{Sources of Funding}

The study was supported by Russian Science Foundation (Grant \#14-25-00019).

\section{Competing interests}

The authors declare that they have no conflict of interest.

\section{References}

1. Prikhodko AG. Respiratory tract response to hypoosmotic stimulus. Bull Physiol Pathol Resp. 2005; 21:47-52. [Article in Russian].

2. Gorbenko PP, Adamova IV, Sinitsyna TM. Bronchial hyperreactivity to the inhalation of hypo- and hyperosmolar aerosols and its correction by halotherapy. Ter Arkh. 1996; 8:24-28. [Article in Russian].

3. Nikitina LYu, Petrovsky FI, Soodayeva SK. Oxidative stress and exercise-induced bronchoconstriction in elite athletes: does the interrelation exist? Pul'monologiya (Pulmonology). 2012; 5:99-104. [Article in Russian].

4. Nevzorova VA, Pazych SA, Barkhatova DA, Kudryavtseva VA. The role of process cell death in course of inflammation under bronchial asthma. Pacific Medical J. 2006; 2:54-8. [Article in Russian].

5. Soodayeva SK. Free radical mechanisms of injury in respiratory disease. Pul'monologiya (Pulmonology) 2012; 1:5-10. [Article in Russian].

6. Anderson SD, Kippelen P. Airway injury as a mechanism for exercise-induced bronchoconstriction in elite athletes. $\mathrm{J}$ Allergy Clin Immunol. 2008; 122(2):225-35.

7. Powers SK, Jackson MJ. Exercise-induced oxidative stress: cellular mechanisms and impact on muscle force production. Physiol Rev. 2008; 88(4):1243-76.

8. Sugiura H, Ichinose M. Nitrative stress in inflammatory lung diseases. Nitric Oxide. 2011; 25(2):138-44.

9. Perelman JM, Prikhodko AG, Borodin EA, Ushakova EV. The role of oxidative stress in airway response to hyposmolar stimulus in patients with bronchial asthma. Bull Physiol Pathol Resp. 2014; 54:17-22.[Article in Russian].

10. Klebanoff SJ. Myeloperoxidase: friend and foe. J Leukos Biol. 2005; 77(5): 598-625.

11. Panasenko OM, Gorudko IV, Sokolov AV. Hypochlorous acid as a precursor of free radicals in living systems. Biochemistry (Mosc). 2013; 78(13):1466-89. [Article in Russian].

12. Gorudko IV, Kostevich VA, Sokolov AV, Shamova EV, Buko IV, Konstantinova EE, et al. Functional activity of neutrophils in diabetes mellitus and coronary heart disease: role of myeloperoxidase in the development of oxidative stress. Bull Exp Biol Med. 2012; 154(1):23-6. [Article in Russian].

13. Perelman JM, Pirogov AB, Prikhodko AG, Zinoviev SV, Kolosov VP, Maltseva TA. Myeloperoxidase of bronchial leukocytes as a biomarker of osmotic bronchial hyperresponsiveness in asthmatics. Eur Respir J. 2015; 46(Supp1.59):PA3872.

14. Pirogov AB, Zinoviev SV, Perelman JM, Semirech UO, Semenova GV, Kolosov AV. The activity of myeloperoxidase of neutrophilic and eosinophilic leukocytes of the induced sputum in patients with bronchial asthma with cold bronchial hyperresponsiveness. Bull Physiol Pathol Resp. 2014; 53:506. [Article in Russian].

15. Global Initiative for Asthma (GINA). Global strategy for asthma management and prevention (Updated 2014). URL: http://www.ginasthma.com.

16. Bakakos P, Schleich F, Alchanatis M, Louis R. Induced 
sputum in asthma: from bench to bedside. Curr Med Chem. 2011; 18(10):1415-22.

17. Hayhoe FGJ, Quaglino D. Hematological cytochemistry. $2^{\text {nd }}$ edition. Churchill Levingstone, 1988.

18. Maltseva TA, Pirogov AB, Kolosov VP, Ushakova EV, Naryshkina SV. Cell composition of induced sputum in patients with uncontrolled asthma and its participation in the formation of cold hyperresponsiveness. Eur Respir J. 2013; 42(Suppl. 57):401.

19. Prikhodko AG, Perelman JM, Pirogov AB, Borodin EA, Ushakova EV, Ul'yanychev NV, et al. Phenotypic differences and peculiarities of inflammation in asthmatics with isolated and combined airway hyperresponsiveness to cold air and distilled water. Bull Physiol Pathol Resp. 2014; 54:8-16. [Article in Russian].

20. Pirogov AB, Prikhodko AG, Perelman JM, Zinov'ev SV, Ushakova EV, Makarova GA, et al. Cellular profile of the induced sputum, the level of myeloperoxidase and neutrophilic blood elastase in patients with bronchial asthma with airway hyperresponsiveness to hyposmolar stimulus. Bull Physiol Pathol Resp. 2015; 57:8-14. [Article in Russian].

21. Kawai Y, Kiyokawa H, Kimura Y, Kato Y, Tsuchiya
K, Terao J. Hypochlorous acid-derived modification of phospholipids: characterization of aminophospholipids as regulatory molecules for lipid peroxidation. Biochemistry. 2006; 45(47):14201-11.

22. Panasenko OM, Arnkhold U, Sergienko VI. Impairment of membrane lipids by hypochlorite. Biochemistry (Moscow) Supplement. Series A: Membrane and Cell Biology. 2002; 19(5):403-34. [Article in Russian].

23. Panasenko OM, Chekanov AV, Vlasova II, Sokolov AV, Ageeva KV, Pulina MO, et al. Influence of ceruloplasmin and lactoferrin on the chlorination activity of leukocyte myeloperoxidase assayed by chemiluminescence. Biophysics. 2008; 53(4):573-81. [Article in Russian].

24. Sokolov AV, Ageeva KV, Pulina MO, Cherkalina OS, Samygina VR, Vlasova II, et al. Ceruloplasmin and myeloperoxidase in complex affect the enzymatic properties of each other. Free Rad Res. 2008; 42(11-12):989-98.

25. Shumyantseva VV, Makhova AA, Bulko TV, Shich EV, Kukes VG, Usanov SA, et al. The effect of antioxidants on electrocatalytic activity of cytochrome P450 $3 \mathrm{~A} 4$. Biochemistry (Moscow) Supplement Series B: Biomedical Chemistry. 2013; 7(2):160-4. [Article in Russian]. 